Science and Sensibility 
The publisher gratefully acknowledges the generous support of the August and Susan Frugé Endowment Fund in California Natural History of the University of California Press Foundation. 


\section{Science and Sensibility}

Negotiating an Ecology of Place

Michael Vincent McGinnis

ㅁ 
University of California Press, one of the most distinguished university presses in the United States, enriches lives around the world by advancing scholarship in the humanities, social sciences, and natural sciences. Its activities are supported by the UC Press Foundation and by philanthropic contributions from individuals and institutions. For more information, visit www.ucpress.edu.

University of California Press

Oakland, California

(C) 2016 by The Regents of the University of California

\section{Library of Congress Cataloging-in-Publication Data}

McGinnis, Michael Vincent, I962- author.

Science and sensibility : negotiating an ecology of place / [Michael Vincent McGinnis].

pages $\mathrm{cm}$

Includes bibliographical references and index.

ISBN 978-0-520-285I9-4 (cloth : alk. paper) - ISBN O-520-285 I9-O (cloth : alk. paper) — ISBN 978-0-520$28520-\mathrm{O}$ (pbk. : alk. paper) - ISBN O-520-28520-4 (pbk. : alk. paper) - ISBN 978-0-520-96075-6 (ebook) — ISBN 0-520-96075-O (ebook)

I. Human ecology. 2. Human ecology--Case studies. 3. Environmental protection--Social aspects. I. Title. GF50.M38 2016 $304.2-\mathrm{dc} 23$

Manufactured in the United States of America

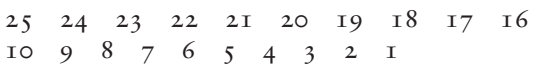

In keeping with a commitment to support environmentally responsible and sustainable printing practices, UC Press has printed this book on Natures Natural, a fiber that contains $30 \%$ post-consumer waste and meets the minimum requirements of ANSI/NISO Z39.48-I992 (R I997) (Permanence of Paper). 
To my Mother, the sea, and my Father, the mountains 
This page intentionally left blank 